\title{
Surgical Treatment Problems of Hydrocephalus Caused by Spontaneus Intraventricular Hemorrhage in Prematurely Born Children
}

\author{
Prematüre Cocuklarda Spontan Intraventriküler Kanama Nedeniyle \\ Hidrosefali Cerrabi Tedavisinin Problemleri
}

\author{
Miljan MIHAJLOVIC ${ }^{1}$, Vojislav BOGOSAVLJEVIC ${ }^{2,3}$, Igor NIKOLIC $^{2,3}$, Milan MRDAK ${ }^{1}$, Nikola REPAC ${ }^{2}$, \\ Vuk SCEPANOVIC ${ }^{2}$, Branislav NESTOROVIC ${ }^{2,3}$, Goran TASIC ${ }^{2,3}$ \\ ${ }^{1}$ University Pediatric Hospital, Department of Neurosurgery, Belgrade, Serbia \\ ${ }^{2}$ Clinical Centre of Serbia, Institute of Neurosurgery, Belgrade, Serbia \\ ${ }^{3}$ Medical Faculty, Belgrade, Serbia
}

Corresponding Author: Vojislav BOGOSAVLJEVIC / E-mail: neurobog1171@gmail.com

\begin{abstract}
AIM: The aim of this study was to identify the most appropriate method of surgical treatment of hydrocephalus in preterm infants that is caused by spontaneous intraventricular hemorrhage (IVH) and to identify predictive factors of poor perioperative outcomes.

MATERIAL and METHODS: We present a series of 60 patients with IVH and hydrocephalus, to whom a VP shunt or subcutaneous (Omaya) reservoir was placed, during the period from March 2006 to March 2011.

RESULTS: Predictors of poor outcome with VP shunt placement were: gestational age $(t=2.323, p=0.024)$, head circumference at birth ( $t=2.072$, $p=0.043)$, birth weight $(t=2.832, p=0.006)$, Apgar score at birth $(t=5.026, p<0.01)$, number of days on assisted ventilation $(Z=6.203, p<0.001)$, peripartal asphyxia $\left(X^{2}=17.376, p<0.01\right)$, respiratory distress $\left(X^{2}=9.176 p=0.002\right)$. Predictors of poor outcome in getting Omaya reservoir are: low birth weight $(t=2.560, p=0.016)$, low Apgar scores $(t=3.059, p=0.005)$, an extended number of days on assisted ventilation $(Z=4.404$, $p<0.001)$, presence of peripartal asphyxia $\left(x^{2}=9.977, p=0.002\right)$ and cardio-respiratory arrest $\left(x^{2}=12.804, p<0.001\right)$.

CONCLUSION: The outcome of hydrocephalus caused by IVH in premature born children is the worst in perinatology. Our results suggest that the main predictive factor is preoperative condition of the child and that the VP shunt and Omaya reservoir are complementary methods of surgical treatment.
\end{abstract}

KEYWORDS: Hydrocephalus, Premature birth, Intraventricular hemorrhage

öz

AMAÇ: Bu çalışmanın amacı, spontan intraventriküler kanama nedeniyle prematüre bebeklerde hidrosefalinin en uygun cerrahi tedavi yöntemini tanımlamak ve kötü perioperatif sonuçlar için prediktif faktörleri belirlemekti.

YÖNTEM ve GEREÇLER: Mart 2006 ile Mart 2011 dönemi arasında bir VP şant veya subkütan (Omaya) rezervuarın yerleştirildiği 60 intraventriküler kanama ve hidrosefali hastası serisi sunulmuştur.

BULGULAR: VP şantı yerleştirme sonrası kötü bir sonucun prediktörleri arasında şunlar vardı: gestasyonel yaş ( $t=2.323, p=0,024)$, doğumda kafa çevresi $(t=2.072, p=0,043)$, doğum ağırlığı $(t=2.832, p=0,006)$, doğumda Apgar skoru $(t=5.026, p<0,01)$, yardımlı ventilasyonlu gün sayısı $(Z=6,203, p<0,001)$, peripartum asfiksi $\left(X^{2}=17,376, p<0,01\right)$, respiratuar distres $\left(x^{2}=9,176 p=0,002\right)$. Omaya rezervuarı ile kötü sonuç prediktörleri arasında şunlar vardı: düşük doğum ağırlığı $(t=2.560, p=0,016)$, düşük Apgar skorları $(t=3.059, p=0,005)$, yardımlı ventilasyonda uzun süre kalma $(Z=4.404, p<0,001)$, peripartum asfiksi varlığı $\left(X^{2}=9.977, p=0,002\right)$ ve kardiyorespiratuar arrest $\left(X^{2}=12.804, p<0,001\right)$.

SONUÇ: Prematüre çocuklarda intraventriküler kanama nedeniyle oluşan hidrosefalinin sonuçları perinatoloji hastalıkları arasında en kötülerinden biridir. Sonuçlarımız ana prediktif faktörün çocuğun preoperatif durumu olduğunu ve VP şant ve Omaya rezervuarının tamamlayıcı cerrahi tedavi yöntemleri olduğunu göstermektedir.

ANAHTAR SÖZCÜKLER: Hidrosefali, Prematüre doğum, İntraventriküler kanama 


\section{INTRODUCTION}

The average number of live births in Serbia per year is 70017. Based on indirect statistical calculations, it is assumed that in Serbia approximately 170-190 children per year is born with hydrocephalus or hydrocephalus and spina bifida. Hydrocephalus occurs in $1 / 500$ children in the general population and almost half are the children born prematurely (15). The frequency of IVH in babies with low body weight exceeds $50 \%(13,55)$. In two reference studies with patients subjected to temporarily surgical treatment of symptomatic hydrocephalus caused by IVH, in 57 or in the $85 \%$ of survivors the placement of the permanent drainage of cerebrospinal fluid was required $(22,26)$. Numerous methods of temporary drainage of cerebrospinal fluid are used in the initial treatment of post haemorrhagic hydrocephalus $(\mathrm{PHH})$ in prematurely born children. These children often do not tolerate the placement of permanent ventriculoperitoneal (VP) shunt as the initial procedure because of the blood in the ventricular system and the high probability of the valve mechanism obstruction caused by the blood decomposition products. A great number of children are physically too small to tolerate the shunt system (valve and tubes) and are prone to dehiscence and skin infections. Inability to absorb liquor distally in the peritoneum may also contribute to shunt failure in this population so temporary drainage of cerebrospinal fluid is often necessary. Temporary medication (acetazolamide, furosemide ...) or invasive treatment (lumbar puncture or transfontanelle ventricular puncture) does not exclude placement of a permanent drainage $(51,53)$. Criteria for treatment depend on the surgeon and institution. In PHH methods of choice are 1) VP shunt and 2) setting up reservoirs of single ventricular periodic puncture (Omaya).

The aim of our study was to identify predictive factors of poor perioperative outcomes and evaluate the possible advantages of one of the proposed methods.

\section{MATERIAL and METHODS}

In order to optimize treatment and surgical treatment of hydrocephalus in premature infants the possibility of a subcutaneous reservoir with ventricular catheter was studied in premature infants in which for some reason (poor general condition or the existence of associated anomalies) ventriculoperitoneal shunt can not be primarily placed as generally accepted method in order to prevent destruction of brain parenchyma due to higher intracranial pressure. This method has been used before, but is (has not been) not generally accepted. The study included 60 patients with intraventricular hemorrhage (IVH) who were treated at the University Children's Hospital in Belgrade and the Institute for
Neonatology in Belgrade from March 2006 to March 2011. By randomized study, we formed two groups of 30 patients with the same characteristics (gestational age, birth weight, APGAR score). The first group included patients who were placed ventriculoperitoneal shunt while the other group consisted of patients who were primarily placed a subcutaneous reservoir with ventricular catheter. Children included in the study were at least 23 weeks of age, IVH was documented by ultrasound, bilateral ventricular dilatation was $4 \mathrm{~mm}$ or more. Ultrasound recording was repeated twice a week with mandatory parental consent. The study excluded children with the values of prothrombin time over 20 seconds or if the thrombocytes level was less than $50000 / \mathrm{mm} 3$.The study was a prospective descriptive-analytical study. All collected data was analyzed using descriptive and analytical statistics, in order to predict the occurrence of the possible complications. Logistic regression method was used. Besides this (in addition to this procedure), we applied the methods of one-factor and two-factor analysis of variance to test the significance of difference between operative techniques. For this process we used the software package SPSS 12.0.

\section{RESULTS}

The study included 60 children who were diagnosed IVH and consequent hydrocephalus during treatment in the University Children's Hospital and the Institute for Neonatology in Belgrade from March 2003. to March 2008. The median width of the ventricle was $16 \mathrm{~mm}(14-22 \mathrm{~mm})$ on the right side and $16 \mathrm{~mm}(14-19 \mathrm{~mm})$ on the left. For data processing and evaluation of the usefulness of the proposed method the patients were divided into two groups: group I with an implanted ventriculoperitoneal shunt (VP) and group II with an implanted subcutaneous reservoir (Omaya reservoir). Each group consisted of 30 patients. The average gestational age in the first group in which we had 15 boys and girls was 29.63 \pm 2.91 weeks of gestation, while the second group of 17 boys and 13 girls was $29.27 \pm 3.33$ weeks of gestation. There was no statistically significant difference in the average gestational age $(t=0.472, p>0.05)$ (Table $\mathrm{l})$, and gender representation between the two groups $(x 2=0.268, p>0.05)$ (Table II).

There was no difference between groups I and II in the timing of surgery $(Z=0.809, p>0.05)$, the average head circumference $(\mathrm{t}=0.853, \mathrm{p}>0.05)$ and body weight $(\mathrm{t}=0.107, \mathrm{p}>0,05)$ (Table III).

In group I, the outcome of the treated patients was affected by gestational age $(t=2.323, p=0.024)$, head circumference at birth $(t=2.072, p=0.043)$, birth weight $(t=2.832, p=0.006)$, Apgar score at birth $(t=5.026, p<0.01)$, number of days on assisted ventilation $(Z=6.203, p<0.001)$, peripartal asphyxia

Table I: Gestational Age in the Experimental and Control Groups (Gestation in Weeks)

\begin{tabular}{|c|c|c|c|c|}
\hline Group & $X^{2}$ & SD & Min & Max \\
\hline I & 29,63 & 2,91 & 25 & 35 \\
II & 29,27 & 3,33 & 24 & 35 \\
\hline
\end{tabular}

$(t=0,472 ; p>0,05)$. 
$(x 2=17.376, p<0.01)$, respiratory distress $(x 2=9.176 p=0.002)$. As the most important predictor of poor treatment outcome an extended number of days on assisted ventilation was marked by multivariate logistic regression analysis $(p<0.05)$ (Table IV).

Using univariate logistic regression analysis, the significant predictors of poor treatment outcome of group II patients were identified: low birth weight $(t=2.560$, $p=0.016)$, low Apgar scores $(t=3.059, p=0.005)$, an extended number of days on assisted ventilation $(Z=4.404$, $p<0.001)$, presence of peripartum asphyxia $\left(X^{2}=9.977\right.$, $p=0.002)$ and cardio-respiratory arrest $\left(x^{2}=12.804, p<0.001\right)$.
By multivariate logistic regression analysis as the most important predictor of poor outcome an extended number of days on assisted ventilation was marked $(p<0.05)$ (Table V).

There was no significant difference in the prevalence of poor $\left(x^{2}=0.271, p>0.05\right)$ and death $\left(x^{2}=0.659, p>0.05\right)$ outcome between the groups. However, group II had 10\% lower mortality than the control group, which may be clinically significant difference, but the size of the sample is insufficient for statistical test to have sufficient power to demonstrate the significance of the differences (Table VI).

\section{DISCUSSION}

Posthaemorrhagic hydrocephalus remains one of the most

Table II: Second Distribution of Infants by Gender

\begin{tabular}{|c|c|c|c|c|}
\hline \multirow{2}{*}{ Gender } & \multicolumn{2}{|c|}{ I group } & \multicolumn{2}{|c|}{ II group } \\
\hline & $\mathbf{N}$ & $\%$ & $\mathbf{N}$ & $\%$ \\
\hline Male & 15 & 50.0 & 17 & 56.7 \\
\hline Female & 15 & 50.0 & 13 & 43.3 \\
\hline Total & 30 & 100.0 & 30 & 100.0 \\
\hline
\end{tabular}

$\left(X^{2}=0,268 ; p>0,05\right)$.

Table III: Time of Surgery, Head Circumference $(\mathrm{cm})$ and Weight $(\mathrm{g})$ at the Time of Placement of VP Shunt

\begin{tabular}{|c|c|c|c|c|}
\hline Group & $\overline{\mathbf{X}}$ & SD & Min & Max \\
\hline \multicolumn{5}{|c|}{ Time of placing VP schant* (days) } \\
\hline I & 47 & 38 & 21 & 143 \\
\hline II & 64 & 34 & 29 & 127 \\
\hline \multicolumn{5}{|c|}{$\begin{array}{l}\qquad(Z=0,809 ; p>0,05) \\
\text { Head circumference }(\mathrm{cm}) \text { in time of operation }\end{array}$} \\
\hline I & 34,65 & 2,78 & 30 & 42 \\
\hline II & 35,47 & 3,01 & 32 & 42 \\
\hline \multicolumn{5}{|c|}{$\begin{array}{l}\qquad(t=0,853 ; p>0,05) \\
\text { Body mass }(g) \text { in time of operation }\end{array}$} \\
\hline 1 & 2253,82 & 895,45 & 1350 & 4950 \\
\hline II & 2282,11 & $\begin{array}{l}684,70 \\
0,107 ; p>\end{array}$ & 1330 & 3500 \\
\hline
\end{tabular}

Table IV: Predictors of Poor Treatment Outcome of the Group I of Patients with IVH

\begin{tabular}{|c|c|c|c|c|c|c|}
\hline \multirow{2}{*}{ Examined characteristics } & \multicolumn{3}{|c|}{ Univariate analysis } & \multicolumn{3}{|c|}{ Multivariate analysis } \\
\hline & $\mathbf{p}$ & $\mathbf{R R}$ & $95 \% \mathrm{Cl}$ & $\mathbf{p}$ & $\mathbf{R R}$ & $95 \% \mathrm{Cl}$ \\
\hline Gestational age & 0,024 & 0,804 & $0,606-0,979$ & / & / & / \\
\hline Birth weight (g) & 0,006 & 0,998 & $0,996-1,000$ & / & / & / \\
\hline Head circumference at birth (cm) & 0,043 & 0,803 & $0,645-1,000$ & / & / & / \\
\hline Apgar score & $<0,001$ & 0,517 & $0,368-0,726$ & / & / & / \\
\hline Number of days on assisted ventilation & $<0,001$ & 1,215 & $1,099-1,343$ & 0,005 & 1,160 & $1,046-1,285$ \\
\hline Peripartal asphyxia & $<0,001$ & 11,667 & $3,384-40,220$ & / & l & / \\
\hline Respiratory distress & 0,002 & 52,800 & $6,209-449,033$ & / & / & / \\
\hline
\end{tabular}


Table V: Predictors of Poor Treatment Outcome Group II Patients with IVH

\begin{tabular}{|c|c|c|c|c|c|c|}
\hline \multirow{2}{*}{ Examined characteristics } & \multicolumn{3}{|c|}{ Univariate analysis } & \multicolumn{3}{|c|}{ Multivriate analysis } \\
\hline & $\mathbf{p}$ & $\mathbf{R R}$ & $95 \% \mathrm{Cl}$ & $\mathbf{p}$ & $\mathbf{R R}$ & $95 \% \mathrm{Cl}$ \\
\hline Birth weight (g) & 0,033 & 0,997 & $0,995-1,000$ & / & l & I \\
\hline Apgar score & 0,014 & 0,543 & $0,334-0,883$ & / & / & / \\
\hline Number of days on assisted ventilation & 0,013 & 1,218 & $1,042-1,424$ & 0,013 & 1,218 & $1,042-1,424$ \\
\hline Peripartal asphyxia & 0,008 & 22,000 & $2,274-212,860$ & / & / & / \\
\hline Cardio-respiratory arrest & 0,003 & 34,000 & $3,253-355,409$ & / & / & / \\
\hline
\end{tabular}

Table VI: Distribution of Infants by to the Representation of Outcome

\begin{tabular}{|c|c|c|c|c|}
\hline \multirow{2}{*}{ Examined characteristics } & \multicolumn{2}{|c|}{ Control $(n=30)$} & \multicolumn{2}{|c|}{$\operatorname{Exp}(n=30)$} \\
\hline & $\mathbf{N}$ & $\%$ & $\mathbf{N}$ & $\%$ \\
\hline \multicolumn{5}{|l|}{ Outcome of the treatment } \\
\hline Poor & 14 & 46,7 & 12 & 40,0 \\
\hline Good/exellent & 16 & 53,3 & 18 & 60,0 \\
\hline \multicolumn{5}{|l|}{$\left(x^{2}=0,271 ; p>0,05\right)$} \\
\hline \multicolumn{5}{|c|}{ Outcome of the treatment - survival } \\
\hline Exitus & 12 & 40,0 & 9 & 30,0 \\
\hline Survived & 18 & 60,0 & 21 & 70,0 \\
\hline$\left(x^{2}=0,659 ; p>0,05\right)$ & & & & \\
\hline
\end{tabular}

common causes of hydrocephalus in childhood. The massive IVH carries a high risk of neurological deficits, and more than $50 \%$ of these children have a progressive development of ventricular dilation. Murphy and colleagues have shown that posthaemorrhagic ventricular dilatation $(\mathrm{PHH})$ caused an increased mortality and morbidity rate in the last decade of twentieth century $(31,49)$. It is important to mention the limitations of any retrospective reports. There are different criteria at each institution at the beginning of treatment, including the initial size of the head, the rate of growth, ventriculomegaly, rate of change in ventricular size. Criteria for temporary and permanent drainage therapy are also not standardized. In many cases, changeable characteristics are 1) the relative weight of the newborn for the permanent placement of drainage, 2) radiographic criteria for bleeding in the ventricles and 3) to temporarily define the need for the therapy or for permanent placement of drainage. In some cases there are differences in criteria depending of institutions and the surgeon.

The treatment of $\mathrm{PHH}$ has followed an increased risk of shunt failure, with medium survival from 2 to 7 years $(12,24,28,34,45)$. Unclear is the ratio of size of the blood clot on the ventricular dilatation and successfulness of surgical intervention. Alternative methods of treatment can delay the treatment of $\mathrm{PHH}$. Surgeons in many medical centers routinely perform LP or direct serial ventricular punctures, by which they control the size of the head. In Cochrane's publication, published in 2001, Whitelaw concluded that repeated puncture is not recommend in neonate with risk of $\mathrm{PHH}$ (51), because there is no statistically significant decrease in shunt placement, mortality and disability, as well as increased incidence of infection in the CSF compared with conservatively treated patients. Also, later in the same review the author concludes that neither the treatment with acetazolamide nor furosemide is unsafe and efficient, and can not be recommended $(53,54)$. They hope that therapy is going to reduce in antifibrolitic therapy to reduce the clot and normalizing the circulation of cerebrospinal fluid $(18,54)$. Whitelaw opposes the use of streptokinase in infants with IVH (52). Therefore it remains as the basis of the surgical treatment. Ventricular subgaleatic maneuvers are described in detail in the literature. A ten-year series of 173 PD patients (University of lowa) from 1977 is the largest and the oldest study (33). Rahman and colleagues published a series of the 17 patients in whom the initial treatment consisted of serial LP (35). In 15 of them a subgaleatic-ventricular drainage was made without complications, from that group 3 patients did not require additional permanent drainage. Subgaleatic shunt may be revised in the case of contraction of subgaleatic pocket when there is a possibility to obstruct a permanent shunt system. The use of subcutaneously embedded reservoir is well known since the eighties of the twentieth century $(10,26)$. The procedure is technically relatively simple and allows the controlled liquor extraction transcutaneous by monitoring of the clinical picture. Reservoir has advantages over repeated lumbar punctures (often a small amount of cerebrospinal fluid) and repeated transcortical ventricular puncture (risk of injury) (1). Major complications in the use of 
reservoirs are liquorhea, infection and skin necrosis $(5,32,37)$. It was considered that intermittent evacuation of liquor from the reservoir affects the normalization of CSF absorption in a subgroup of children with $\mathrm{PHH}$, thereby avoiding a permanent VP drainage $(7,32,37)$.

The most often used method in the treatment of hydrocephalus is shunt system that enables drainage of liquor in the other body cavity in order to reduce intracranial pressure caused by accumulation of liquor in the ventricles. Although if the adequate drainage may not be achieved by using subcutaneous reservoirs in cases of premature infants with low weight and cerebral cortex thickness less than $1 \mathrm{~cm}$ and large ventricles on the US, VP shunt is not preferred because of the insufficient immune system and adequate resorption in the stomach, not efficient absorption of blood from the decay products of liquor in the ventricular system and insufficient development of the subcutaneous tissue. It is recommended that we should wait until the weight reaches 2000 grams, rather than try with drainage $(16,36)$. During this period of monitoring the solution that is least harmful and prevents complications is ventricular or lumbar puncture, with principles of antisepsis to reduce the risk of meningitis. External drainage of liquor increases the risk of infection and is burdened by the possibility of excessive drainage (over drainage), with abnormal electrolytes and proteins.

The timing for the placement of subcutaneous reservoir in premature children with hydrocephalus is a contentious issue and we know only about two different views on this subject that were elaborated in two published studies. Willis and colleagues say the 30-day period (4.2 weeks), and Fulmer and associates 28 days (4 weeks). VP shunt placement in the early period in preterm infants with $\mathrm{PHH}$ may be associated with the increased incidence of shunt infection and high rate of its obstruction (19). Taylor and colleagues have published in 2001, 36 cases in which the VP shunt was installed in the delay term, because it takes at least 5 weeks for the resorption of blood from the ventricle. This drainage was performed after the middle period of 42 days. In 9 patients (25\%) there was an obstruction of the shunt and 21 revisions were made (41). They have not prescribed any therapy during 42 days for protection of white matter. But in massive IVH a very rapid clinical changes are possible and also the rapid development of hydrocephalus, and in these situations an early VPS is recommended $(19,20,36,41,55)$. Levi and colleagues had $83 \%$ obstruction of shunt in preterm infants with $\mathrm{PHH}$ (in $83 \%$ of cases). Lin had in $89 \%$ of cases, $94 \%$ (of cases) of the McCallum and Scarff in $50 \%$ shunt obstruction (and Scarf had shunt obstruction in $50 \%$ of cases) $(22,23,25,38,41)$.

Tubbs and colleagues report that the timing for the VP shunt was 37.4 days, and Fulmer and his associates said that it is of the uppermost importance to pass at least one month before VP implantation so that IVH can be resorbed (44). The Permanent VP drainage in premature infants with $\mathrm{PHH}$ is needed in 60 to $85 \%(1,6,13,31,40,43)$. According to Willis it was necessary in $83.4 \%, 84 \%$ Tubbs, Fulmer and Rachman $75 \%$ and Skara 90\%. $(9,35,39,44,55)$. For other methods of treatment dependency for the shunt percent varies for external drainage from 64 to $78 \%$ and for the application of a subcutaneous reservoir $75-88 \%(3,46)$. Infection rate after placement a VP shunt in $\mathrm{PHH}$ is $33 \%$ according to Fuler. In our study VPS was made after the intermediate waiting period of 47 days. It may seem late in relation to the literature, but we insisted that the children must reach 2000 grams in weight. Complications that are registered with the placement of subcutaneous reservoir are liquohrea, meningitis, catheter migration from the ventricle or its slippage into the ventricle and intraparenchimal haemorrhage $(9,55)$. Liquorea rate on skin incision, according to Willis is $16.6 \%$, and $4.7 \%$ according to Tubbs, 5\% according to Fulmer and $32 \%$ according to Sklar $(9,17,39,55)$. In our study liquohrea occurred in $23 \%$ of cases (7 patients), which is the upper limit of the mean incidence in the available published literature. Revision was required in 52 out of 185 cases in Tubbs (28\%) and in 5 of 20 patients Fulmer $(9,44)$.

Several studies showed that gestational age is directly related with the development of IVH and associated cognitive and neurological deficits $(2,14,21,27,29,30,42,47,50)$.

IVH usually occurs within the first 24 hours after birth and progression of hemorrhage is possible after 48 hours or longer. By the end of the first week $90 \%$ of hemorrhage can be detected and the period of risk is independent of gestational age. The treatment of IVH is typically related to screening of IVH consequences and treatment of neonates (respiratory status and blood pressure that may indicate the progression of IVH). Parameters of the American Academy of Neurology "neonatal neuroimaging " suggest US screening of preterm neonates under 30 weeks of gestation twice. The first US is recommended between the 7th and the 14th day of age in order to discover traces of IVH and the second after 36-40 weeks from last menstrual period of the mother to see the possible effects of CNS lesions such as periventricular leukomalacia and ventriculomegaly. Later, MRI is a better method for the detection of lesions in the white matter. Posthaemorrhagic hydrocephalus $(\mathrm{PHH})$ and periventricular leukomalacia (PVL) are two important sequel of IVH. Patients with $\mathrm{PHH}$ usually have a rapid growth of head circumference, growth of ventricle on radiological examinations and signs of increased intracranial pressure, but the signs and symptoms of hydrocephalus may not be seen for several weeks after the hemorrhage due to compliance of the neonatal brain. (48)

Most patients with $\mathrm{PHH}$ are with communicating hydrocephalus, which occurs secondary due to chemical arachnoiditis after the dissolution of blood in the cerebrospinal fluid. Hydrocephalus may be obstructive due to acute obstruction of the aqueduct or Monro opening because of subependimal creation of the scars $(4,8,11)$.

\section{CONCLUSION}

According to the U.S. Census Bureau, the NICHD neonatal network and center for the disease control in the United States annually registers approximately 3,600 cases of mental retardation caused by IVH and their care will cost 3.6 billion 
dollars(and that the cost of the health care that they will need will reach the 3.6 billion dollars).

The composition of our group was operated, unselected patients. It is likely that the percentage of survival would be greater in the case of stricter criteria for surgical intervention. However, this entails a series of medical-ethical issues that may not be appropriate, but for now, there are no clearly defined parameters for a good prognosis. Therefore, this question remains open. Our results suggest that the main predictive factor is preoperative condition of the child and that the VP shunt and Omaya reservoir are complementary methods of surgical treatment. Significant predictors of poor treatment outcome were identified: low birth weight, low Apgar scores, extended number of days on assisted ventilation, presence of peripartum asphyxia and cardio-respiratory arrest.

In fact, those few cases of Hydrocephalus in premature infants who did not undergo surgery were indeed very complex examples of hydrocephalus with multiple malformations that are always incompatible with protracted perinatal survival. Only in these cases from the beginning we believed that with surgery we could not achieve anything.

\section{REFERENCES}

1. Ventriculomegaly Trial Group: Randomised trial of early tapping in neonatal posthaemorrhagic ventricular dilatation. Arch Dis Child 65:3-10, 1990

2. Anderson A, Swank P, Wildin S: Modeling analysis of change of neurologic abnormalities in children born prematurely: $A$ novel approach. J Child Neurol 14:502-508, 1999

3. Arslan M, Eseoglu M, Gudu BO, Demir I, Kozan A, Gokalp A, Sosuncu $E$, Kiymaz $N$ : Comparison of simultaneous shunting to delayed shunting in infants with myelomeningocele in terms of shunt infection rate. Turk Neurosurg 21:397-402, 2011

4. Banker BQ, Larroche JC: Periventricular leukomalacia of infancy. A form of neonatal anoxic encephalopathy. Arh Neurol 7:386-410, 1962

5. Brouwer AJ, Groenendaal F, van den Hoogen A, VerboonMaciolek M, Hanlo P, Rademaker KJ, de Vries LS: Incidence of infections of ventricular reservoirs in the treatment of posthaemorrhagic ventricular dilatation: A retrospective study (1992-2003). Arch Dis Child Fetal Neonatal Ed 92:F41-43, 2007

6. Cornips E, Van Calenbergh F, Plets C, Devlieger H, Casaer P: Use of external drainage for posthemorrhagic hydrocephalus in very low birth weight premature infants. Child Nerv Syst 13:369-374, 1997

7. de Vries LS, Liem KD, van Dijk K, Smit BJ, Sie L, Rademaker KJ, Gavilanes AW; Dutch Working Group of Neonatal Neurology: Early versus late treatment of posthaemorrhagic ventricular dilatation: Results of a retrospective study from five neonatal intensive care units in The Netherlands. Acta Paediatr 91: 212-217, 2002

8. Deguchi K, Oguchi K, Takashima S: Characteristic neuropathology of leukomalacia in extremely low birth weight infants. Pediatr Neurol 16:296-300, 1997
9. Fulmer BB, Grabb PA, Oakes WJ, Mapstone TB: Neonatal ventriculosubgaleal shunts. Neurosurgery 47:80-83, 2000

10. Gaskill SJ, Martin AE, Rivera S: The subcutaneous ventricular reservoir: An effective treatment for posthemorrhagic hydrocephalus. Child Nerv Syst 4:291-295, 1988

11. Grant EG, Schellinger D, Smith Y, Uscinski RH: Periventricular leukomalacia in combination with intraventricular hemorrhage: Sonographic features and sequelae. AJNR Am J Neuroradiol 7:443-447, 1986

12. Griebel R, Khan M, Tan L: CSF shunt complications: An analysis of contributory factors. Child Nerv Syst 1:77-80, 1985

13. Gurtner P, Bass T, Gudeman SK, Penix JO, Philput CB, Schinco FP:Surgical management of posthemorrhagic hydrocephalus in 22 low-birth-weight infants. Childs Nerv Syst 8:198-202, 1992

14. Hansen BM, Dinesen J, Hoff B, Greisen G: Intelligence in preterm children at four years of age as a predictor of school function: A longitudinal controlled study. Dev Med Child Neurol 44:817-821, 2002

15. Hintz SR, Poole WK, Wright LL, Fanaroff AA, Kendrick DE, Laptook AR, Goldberg R, Duara S, Stoll BJ, Oh W; NICHD Neonatal Research Network: Changes in mortality and morbidities among infants born at less than 25 weeks during the postsurfactant era. Arch Dis Child Fetal Neonatal Ed 90:F128-133, 2005

16. Horinek D, Cihar M, Tichy M: Current methods in the treatment of posthemorrhagic hydrocephalus in infants. Bratisl Lek Listy 104:347-351, 2003

17. Hudgins RJ, Boydston WR, Gilreath CL: Treatment of posthemorrhagic hydrocephalus in the preterm infant with a ventricular access device. Pediatr Neurosurg 29:309-313, 1998

18. Hudgins RJ, Boydston WR, Hudgins PA, Adler SR: Treatment of intraventricular hemorrhage in the premature infant with urokinase. A preliminary report. Pediatr Neurosurg 20: 190-197, 1994

19. Kadri H, Mawla AA, Kazah J: The incidence, timing, and predisposing factors of germinal matrix and intraventricular hemorrhage $(\mathrm{GMH} / \mathrm{IVH})$ in preterm neonates. Childs Nerv Syst 22:1086-1090, 2006

20. Kazan S, Gura A, Ucar T, Kormaz E, Ongun H, Akyuz M: Hydrocephalus after intraventricular hemorrhage in preterm and low-birth weight infants: Analysis of associated risk factors for ventriculoperitoneal shunting. Surg Neurol 64: 77-81, 2005

21. Koller H, Lawson K, Rose SA:Patterns of cognitive development in very low birth weight children during the first six years of life. Pediatrics 99:383-389, 1997

22. Levy ML, McComb JG: Outcome for preterm infants with germinal matrix hemorrhage and progressive hydrocephalus. Neurosurgery 41:1111-1118, 1997

23. Lin JP, Goh W, Brown JK, Steers AJW: Neurological outcome following neonatal post-haemorrhagic hydrocephalus: The effects of maximum raised intracranial pressure and ventriculo-peritoneal shunting. Child Nerv Syst 8:190-197, 1992 
24. Liptak GS, McDonald JV: Ventriculoperitoneal shunts in children: Factors affecting shunt survival 12:289-293, 1985

25. McCallum J, Turbeville D: Cost and outcome in a series of shunted premature infants with intraventricular hemorrhage. Pediatr Neurosurg 20:63-67, 1994

26. McComb JG, Ramos AD, Platzker AC, Henderson DJ, Segall HD: Management of hydrocephalus secondary to intraventriculare hemorrhage in preterm infant with subcutaneous ventricular catheter reservoir. Neurosurgery 13:295-300, 1983

27. McCormick MC, Gortmaker SL, Sobel AM: Very low birth weight children: Behavior problems and school difficulty in a national sample. J Pediatr 117:687-693, 1990

28. McGirt MJ, Leveque JC, Wellons JC III, Villavicencio AT, Hopkins JS, Fuchs HE, Georg TM: Cerebrospinal fluid shunt survival and etiology of failures: A seven-year institutional experience. Pediatr Neurosurg 36:245-255, 2002

29. Ment LR, Vohr B, Allan W, Katz KH, Schneider KC, Westerveld M, Duncan CC, Makuch RW: Change in cognitive function over time in very low-birth-weight infants. JAMA 289: 705-711, 2003

30. Morris BH, Smith KE, Swank PR, Denson SE, Landry SH: Patterns of physical and neurologic development in preterm children. J Perinatol 22:31-36, 2002

31. Murphy BP, Inder TE, Rooks V, Taylor GA, Anderson NJ, Mogridge N, Horwood LJ, Volpe JJ: Posthaemorrhagic ventricular dilatation in the premature infant: Natural history and predictors of outcome. Arch Dis Child Fetal Neonatal Ed 87:F37-41, 2002

32. Peretta P, Ragazzi $P$, Carlino CF, Gaglini $P$, Cinalli G: The role of Ommaya reservoir and endoscopic third ventriculostomy in the management of post-hemorrhagic hydrocephalus of prematurity. Child Nerv Syst 23:765-771, 2007

33. Perret GE, Graf CJ: Subgaleal shunt for temporary ventricle decompression and subdural drainage. J Neurosurg 47: 590-595, 1977

34. Piatt JH Jr, Carlson CV: A search for determinants of cerebrospinal fluid shunt survival: Retrospective analysis of a 14-year institutional experience. Pediatr Neurosurg 19: 233-242, 1993

35. Rahman S, Teo C, Morris W, Lao D, Boop FA: Ventriculosubgaleal shunt: A treatment option for progressive posthemorrhagic hydrocephalus. Childs Nerv Syst 11:650-654, 1995

36. Reinprecht A, Dietrich W, Berger A, Bavinzski G, Weninger $M$, Czech T: Posthemorrhagic hydrocephalus in preterm infants: Long-term follow-up and shunt-related complications. Child Nerv Syst 17:663-669, 2001

37. Richard E, Cinalli G, Assis D, Pierre-Kahn A, Lacaze-Masmonteil T: Treatment of post-haemorrhage ventricular dilatation with an Ommaya's reservoir: Management and outcome of 64 preterm infants. Childs Nerv Syst 17:334-340, 2001

38. Roland EH, Hill A: Intraventricular hemorrhage and posthemorrhagic hydrocephalus. Current and potential future interventions. Clin Perinatol 24:589-605, 1997

39. Sklar F, Adegbite A, Shapiro K, Miller K: Ventriculosubgaleal shunts: Management of posthemorrhagic hydrocephalus in premature infants. Pediatr Neurosurg 18:263-265, 1992
40. Steinbok P, Cochrane DD: Ventriculosubgaleal shunt in the management of recurrent ventriculoperitoneal shunt infection. Child Nerv Syst 10:536-539, 1994

41. Taylor AG, Peter JC: Advantages of delayed VP shunting in post-haemorrhagic hydrocephalus seen in low-birth-weight infant. Childs Nerv Syst 17:328-333, 2001

42. Tommiska V, Heinonen K, Kero P, Pokela ML, Tammela O, Järvenpää $A L$, Salokorpi T, Virtanen $M$, Fellman V: A national two year follow up study of extremely low birthweight infants born in 1996-1997. Arch Dis Child Fetal Neonatal Ed 88:F2935, 2003

43. Tortorolo $G \mathrm{~L}$, ciano $\mathrm{R}$, Papacci $\mathrm{P}$, Tonelli $\mathrm{T}$ : Intraventricular hemorrhage: Past, present and future, focusing on classification, pathogenesis and prevention. Child Nerv Syst 15:652-661, 1999

44. Tubbs RS, Smyth MD, Wellons JC, Blount JP, Grabb PA, Oakes WJ: Life expectancy of ventriculosubgaleal shunt revisions. Pediatr Neurosurg 38:244-246, 2003

45. Tuli S, Drake J, Lawless J, Wigg M, Lamberti-Pasculli M: Risk factors for repeated cerebrospinal shunt failures in pediatric patients with hydrocephalus. J Neurosurg 92:31-38, 2000

46. Turhan T, Ersahin Y: Indirect bypass procedures for moyamoya disease in pediatric patients. Turk Neurosurg 21:161-166, 2011

47. Vollmer B, Roth S, Baudin J, Stewart AL, Neville BG, Wyatt JS: Predictors of long-term outcome in very preterm infants: Gestational age versus neonatal cranial ultrasound. Pediatrics 112:1108-1114, 2003

48. Volpe JJ: Brain injury of premature infant-from pathogenesis to prevention. Brain Dev 19:519-534, 1997

49. Volpe JJ: Neurology of the Newborn. 4th. ed. Philadelphia: Saunders, 2001

50. Whitaker AH, Feldman JF, Van Rossem R, Schonfeld IS, Pinto-Martin JA, Torre C, Blumenthal SR, Paneth NS: Neonatal cranial ultrasound abnormalities in low birth weight infants: Relation to cognitive outcomes at six years of age. Pediatrics 98:719-729, 1996

51. Whitelaw A: Repeated lumbar or ventricular punctures in newborns with intraventricular hemorrhage. Cochrane Database Syst Rev 1: CD000216, 2001

52. Whitelaw A, Evans D, Carter $M$, Thoresen $M$, Mandera $M$, Swietlinski J, Simpson J, Hajivassilou C, Hunt LP, Pople I: Randomized clinical trial of prevention of hydrocephalus after intraventricular hemorrhage in preterm infants: Brain washing versus tapping fluid. Pediatrics 119:1071-1078, 2007

53. Whitelaw A, Kennedy CR, Brion LP: Diuretic therapy for newborn infants with posthemorrhagic ventricular dilatation. Cochrane Database Syst Rev 2:CD002270, 2001

54. Whitelaw A, Pople I, Cherian S, Evans D, Thoresen M: Phase 1 trial of prevention of hydrocephalus after intraventricular hemorrhage in newborn infants by drainage, irrigation, and fibrinolytic therapy. Pediatrics 111:759-765, 2003

55. Willis BK, Kumar CR, Wylen EL, Nanda A: Ventriculosubgaleal shunts for posthemorrhagic hydrocephalus in premature infants. Pediatr Neurosurg 41:178-185, 2005 